\title{
Depreciação em bens de infraestrutura: Um estudo realizado na rodovia
}

\author{
Nova Imigrantes.
}

\author{
Éder de Souza Diógenes \\ Graduado em Contabilidade - Universidade de São Paulo, USP \\ Funcionário da área financeira da Universidade de São Paulo,USP \\ Rua do Matão, Travessa 14, no․ 321, Cidade Universitária, 05508090 - São Paulo, SP. \\ eder@ib.usp.br \\ Valmor Slomski \\ Doutor em Controladoria e Contabilidade - Universidade de São Paulo, USP \\ Prof.da Faculdade de Economia Administração e Contabilidade na Universidade de São Paulo, USP \\ Rua Professor Luciano Gualberto, 908, Cidade Universitária, 05508900 - São Paulo, SP \\ valmor@usp.br
}

\begin{abstract}
Este trabalho teve como objetivo estudar uma metodologia de depreciação para bens de infra-estrutura, mais especificamente na construção e manutenção de estradas de rodagem. Verificar a aplicabilidade e os possíveis reflexos deste método nos balanços de entidades da administração pública direta no intuito de alcançar maior transparência nas demonstrações contábeis destas entidades, tendo em vista o fato de que, nos últimos anos os estudos sobre a forma de reconhecimento e evidenciação de bens públicos de infraestrutura vêm sendo intensificados, mas as metodologias para depreciação destes bens ainda não foram definidas. Para tanto se realizou uma revisão bibliográfica sobre técnicas de depreciação previstas na lei e recomendadas como práticas contábeis corretas no tocante aos bens de infra-estrutura. Abordou-se também a teoria sobre a "Contabilidade por Renovação", metodologia aplicada em alguns países europeus, e as opiniões do IFAC e GASB a respeito deste tipo de bens do ativo imobilizado e sua depreciação. Posteriormente, fez-se um estudo de caso baseado em dados da construção da rodovia Nova Imigrantes, que liga a Capital de São Paulo ao litoral paulista, concessionada à Empresa Ecovias dos Imigrantes S.A., verificando-se a possível aderência deste método às demonstrações contábeis dos entes da administração pública.
\end{abstract}

Palavras-chave: Depreciação, evidenciação, bens públicos de infra-estrutura, ativo imobilizado.

\section{Depreciation in property of infrastructure: A study in the highway nova imigrantes}

This work has as goal to study a methodology of depreciation for property of infrastructure specifically in the building and maintain of highways. To verify the applicability and the possible reflections of this method in institution balance of public administration with the objective to reach a better transparency in their account demonstrations. In view of this, in the last years the studies about the form of recognition and disclosure of infrastructure public goods have been intensified, but the methodologies for their depreciation are still not defined. Therefore was presented a bibliography revision about the depreciation techniques under law that are recommended as right account practices in property of infrastructure. Another point discussed in this text is the theory about "Renovation Account", methodology applied in some European countries, and the opinions of IFAC and GASB about this kind of fixed asset and its depreciation. After that was created a case study based on the construction data of Nova Imigrantes road system, that link the metropolitan region of the capital of the State of Sao Paulo with Santos Coastal Region and is concessional by Empresa Ecovias dos Imigrantes S.A., and was verified the possible adherence of the method in the account demonstrations of the institution of public administration.

Key-words: Depreciation, Disclosure, Infrastructure Public property, Fixed Asset. 


\section{Introdução}

O estudo do reconhecimento de bens públicos de infra-estrutura tem sido pouco explorado pelos pesquisadores ligados a área. Isto se dá em parte, porque a Lei №. 4.320/64 contempla a depreciação de ativos imobilizados apenas para as entidades públicas da administração indireta, ou seja, fundações, autarquias, etc. E, em parte, porque a visão dos gestores contábeis da área é de que os bens de uso público não são de propriedade dos Órgãos Públicos, pois são de uso direto da sociedade, não são mensuráveis de modo confiável, não são vendáveis, não produzem fluxo de caixa para a entidade que os controla, e não possuem alternativa de uso, conforme assinalado por Carvalho e Slomski (2006).

Já Carvalho (2004) argumenta que o problema mais recorrente na literatura especializada sobre processo de depreciação dos bens públicos de infra-estrutura é a questão da vida útil que é dificilmente estimada por dois motivos. Primeiro, porque esses tipos de ativos são, na realidade, um sistema formado por outros ativos menores e esses ativos menores possuem vida útil diferente do ativo de infra-estrutura como um todo e diferentes entre si. Em segundo lugar, porque as partes dos bens públicos de infra-estrutura, ou os ativos que os compõem são freqüentemente renovados, com isso a capacidade de serviços do ativo como um todo é constantemente reestruturada de forma parcial. Mas não basta apenas reconhecer e evidenciar os bens de infra-estrutura, há também que definir metodologias para depreciá-los.

A Lei de Responsabilidade Fiscal (Lei Complementar N $\cong 101$ de 04 de maio de 2000), em seu parágrafo primeiro especifica que "a responsabilidade na gestão fiscal pressupõe a ação planejada e transparente, em que se previnem riscos e se corrigem desvios capazes de afetar o equilíbrio das contas públicas". Nesta responsabilidade reside a importância deste estudo, na medida em que as informações a respeito da aplicação do dinheiro público com o intuito de construção de Bens de Infra-estrutura e sua manutenção, seja originário de receita tributária ou de operações de crédito, tornar-se-ão de fácil entendimento para o principal usuário destes bens, se estes ativos fizerem parte do ativo público e a sua depreciação esteja evidenciada.

Tendo em vista a quase inexistência de bibliografia a respeito do assunto, tomou-se como referencial teórico o Manual de Contabilidade das Sociedades por Ações (Fipecafi, 2007) e citações de autores considerados como expoentes nacionais das matérias que compreendem as normas e melhores práticas contábeis em vigor no Brasil. 
A fundamentação teórica está dividida em quatro partes; a primeira com um breve resumo a respeito da classificação dos bens que podem ser considerados de infra-estrutura e, portanto, passíveis de depreciação; a segunda definindo o que é depreciação; a terceira explicando o que é permitido pela Secretaria da Receita Federal para fins de Imposto de Renda no tocante à contabilização da depreciação. Na quarta e última parte acrescentou-se a Teoria da Contabilidade por Renovação, apresentada por Carvalho (2004), que é uma opção plausível para a contabilização da depreciação dos bens de infra-estrutura, objeto de estudo.

O objetivo deste artigo é estudar uma metodologia de depreciação para bens de uso comum/infra-estrutura e verificar a viabilidade da implementação deste método em demonstrações contábeis das entidades da administração pública direta. Espera-se com isso, diminuir a assimetria de informações existente entre o governo e o cidadão que utiliza estes bens. Para isso, focou-se com maior ênfase no que tange a benfeitorias e construções de estradas de rodagem. A rodovia analisada faz parte do complexo viário que liga a capital ao litoral do estado de São Paulo e é administrada pela Empresa Ecovias dos Imigrantes S.A.. A escolha se deu em virtude desta ser a mais nova rodovia construída no estado e, portanto, possui dados mais atualizados. Estes dados foram coletados nas demonstrações contábeis da empresa.

\section{Fundamentação Teórica}

De acordo com Carvalho (2004), o termo "ativo" não se faz muito presente na literatura contábil brasileira dirigida ao setor governamental. Autores desta área e até a própria Lei № 4.320/64 optam pela utilização de termos como bens 
I - os de uso comum do povo, tais como rios, mares, estradas, ruas e praças;

II - os de uso especial, tais como edifícios ou terrenos destinados a serviço ou estabelecimento da administração federal, estadual, territorial ou municipal, inclusive os de suas autarquias;

III - os dominicais, que constituem o patrimônio das pessoas jurídicas de direito público, como objeto de direito pessoal, ou real, de cada uma dessas entidades.

Parágrafo único. Não dispondo a lei em contrário, consideram-se dominicais os bens pertencentes às pessoas jurídicas de direito público a que se tenha dado estrutura de direito privado.

Nas Normas Internacionais de Contabilidade (IBRACON, 1998) há uma referência de que os ativos imobilizados são ativos tangíveis que: são mantidos por uma empresa para uso na produção ou fornecimento de mercadorias ou serviços; para locação a terceiros; ou para finalidades administrativas; e conforme a expectativa deverão ser usados por mais de um período.

Depreciação é a alocação sistemática do valor depreciável de um ativo ao longo da sua vida útil. Valor depreciável é o custo de um ativo, ou outro valor que figure nos livros em lugar do custo do ativo, menos o seu valor residual. Vida útil é: (a) o período durante o qual se espera que o ativo seja usado pela empresa; ou (b) o número de unidades produzidas ou unidades semelhantes que se espera que sejam obtidas do ativo pela empresa.

Custo é o montante pago em dinheiro ou equivalente, ou o valor justo de outra forma de pagamento entregue para adquirir um ativo na data de sua aquisição ou construção.

Valor residual é o montante líquido que a empresa espera obter por um ativo no fim de sua vida útil, depois de deduzir os custos esperados para vender o ativo. Valor justo é o montante pelo qual um ativo poderia ser vendido entre partes conhecedoras do assunto e dispostas a negociar numa transação sem favorecimentos. Valor contábil ou em livros é o montante pelo qual o ativo é incluído no balanço, depois de deduzir a respectiva depreciação acumulada.

Valor recuperável é o montante que a empresa espera recuperar mediante uso futuro de um ativo, inclusive o seu valor residual por ocasião da venda. Um item do ativo imobilizado deve ser reconhecido como um ativo, quando: (a) for provável que futuros benefícios econômicos 
decorrentes do ativo sejam percebidos pela empresa; e (b) o custo do ativo para a empresa puder ser medido com segurança. Um bem do imobilizado que satisfaz os requisitos de reconhecimento como ativo deve inicialmente ser avaliado pelo custo.

A Lei no. 6.404/76, em seu art. 179, item IV, conceitua como contas as serem classificados no ativo imobilizado: "os direitos que tenham por objeto bens destinados a manutenção das atividades da companhia e da empresa, ou exercido com essa finalidade, inclusive os de propriedade industrial ou comercial".

Segundo Fipecafi (2007), desta definição subentende-se que neste grupo de contas do balanço são incluídos todos os bens de permanência duradoura, destinados ao funcionamento normal da sociedade e de seu empreendimento, assim como os direitos exercidos com essa finalidade.

Os itens classificados na categoria de ativo imobilizado incluem: bens tangíveis, que tem um corpo físico, tais como: terrenos, obras civis, máquinas, móveis, veículos, benfeitorias em propriedades arrendadas, direitos sobre recursos naturais, etc.

A mesma fonte indica que seus preceitos são aplicados às demais sociedades, e é considerada a obra básica para qualquer estudo referente à contabilidade no Brasil. Utilizou-se esta definição para embasar este trabalho no que diz respeito a bens ou ativos de infraestrutura, haja vista que as estradas de rodagem pavimentadas são obras civis, e para o estudo de caso a Concessionária detentora do direito de explorar a Rodovia dos Imigrantes efetua benfeitorias em propriedades, que embora não sejam arrendadas e sim concessionadas, geram o mesmo efeito. Marion (1998) explica que a maior parte dos ativos imobilizados (exceção feita praticamente a terrenos e obras de arte) têm vida útil limitada, ou seja, serão úteis à empresa por um conjunto de períodos definidos, também chamados períodos contábeis. À medida que esses períodos forem decorrendo, dar-se-á o desgaste dos bens, que representam o custo a ser registrado.

O custo do ativo imobilizado é destacado como uma despesa nos períodos contábeis em que o ativo é utilizado pela empresa. O processo contábil para esta conversão gradativa do ativo imobilizado em despesa chama-se depreciação.

A depreciação é uma despesa porque todos os bens e serviços consumidos por uma empresa são despesas. Poderá ser computada como custo (despesa), em cada exercício, a 
importância correspondente à diminuição do valor dos bens do ativo imobilizado resultantes do desgaste pelo uso, ação da natureza e obsolescência.

\subsection{Conceito de Depreciação}

Segundo a Fipecafi (2007), com exceção de terrenos e de alguns outros itens, os elementos que integram o ativo imobilizado têm um período limitado de vida útil econômica. Dessa forma, o custo de tais ativos deve ser alocado aos exercícios beneficiados por seu uso no decorrer de sua vida útil econômica. A esse respeito, o art. 183, $\S 2^{\circ}$, da Lei ํㅜ. 6.404/76 estabelece:

A diminuição de valor dos elementos do ativo imobilizado será registrada periodicamente nas contas de: (a) depreciação quando corresponder á perda do valor dos direitos que têm por objeto bens físicos sujeitos a desgaste ou perda de utilidade por uso, ação da natureza ou obsolescência (...).

Martins (1992) assinala que depreciação é um conceito utilizado na contabilidade, que tem provocado inúmeras discussões e colocações provenientes de diferentes (para não dizer, às vezes, de maus) entendimentos. É um conceito contábil voltado ao passado. Diz respeito à uma parte de um valor investido originariamente no passado e que precisa ser diminuído das receitas de agora, para que o lucro corresponda efetivamente ao montante recebido que excede o valor anteriormente aplicado.

Depreciação em contabilidade é a baixa que se efetua de um valor investido porque se trata de um valor perdido, e porque lucro é exclusivamente o que se recebe em excesso ao valor investido. Muita confusão tem sido criada, principalmente, pela inadequada utilização da expressão "fundo de depreciação", porque ela dá a impressão de que a depreciação é para se repor no futuro o equipamento ou outro ativo ora sendo utilizado, e tendo o seu valor diminuído. Porém em contabilidade, a depreciação não tem essa finalidade, mas sim a de recuperação do valor anteriormente aplicado.

A depreciação é, portanto, o quanto da receita é recuperação de investimento feito no passado. Daí a razão da depreciação ser efetivamente um encargo da empresa a ser sempre diminuído das receitas para a apuração de um resultado adequado. De acordo com ludícibus et al.(2001), depreciação é o desgaste teórico de um ativo imobilizado em virtude do uso, da ação dos elementos naturais, de acidentes e de obsolescência.

\subsection{Métodos de depreciação}


O método de depreciação selecionado deve ser aplicado consistentemente de um período a outro, a menos que circunstâncias alteradas justifiquem uma mudança. No período contábil no qual o método é alterado, o efeito da mudança deve ser quantificado e divulgado, e as razões que motivaram a mudança devem ser expostas.

De acordo com o Ibracon (1998), existem vários métodos sistemáticos para distribuir as importâncias depreciáveis a cada período contábil durante a vida útil dos ativos. Qualquer que seja o método de depreciação selecionado é necessário aplicá-lo consistentemente, independentemente do nível de rentabilidade da empresa e de considerações tributárias, para manter a comparabilidade dos resultados das operações da empresa de um período a outro.

Existem vários métodos para calcular a depreciação, e os autores pesquisados citam como mais importantes os abaixo exemplificados. Para não tornar a leitura repetitiva, faz-se uso das definições da Fipecafi (2007) conforme segue:

a) Método das quotas constantes: A depreciação por este método é calculada dividindo-se o valor a ser depreciado pelo tempo de vida útil do bem, e é representada pela seguinte fórmula:

Depreciação $=\frac{\begin{array}{l}\text { Custo } \\ \text { contabilizadas) menos valor residual estimado. }\end{array}}{\text { Período de vida útil }}$

Esse método, impropriamente chamado de linear, devido a sua simplicidade, é utilizado pela maioria das empresas.

b) Método da soma dos dígitos dos anos: esse método (que também é linear) é calculado somando-se os algarismos que compõem o número de anos de vida útil do bem. Supondo-se cinco anos de vida útil ter-se-ia:

$$
1+2+3+4+5=15
$$

A depreciação de cada ano é uma fração em que o denominador é a soma dos algarismos conforme obtido acima, e o numerador é, para o primeiro ano $(n)$, para o segundo $(n-1)$, para o terceiro $(n-2)$ e assim por diante; em que $n=$ número de anos de vida útil. Esse método proporciona quotas de depreciação maiores no início e menores no fim da vida útil. Permite maior uniformidade nos custos, já que os bens, quando novos, necessitam de pouca manutenção e reparos. Com o passar do tempo os referidos encargos tendem a aumentar. ABCustos Associação Brasileira de Custos - Vol. 3 n³, 91-110 - set/dez 2008 
Esse crescimento das despesas de manutenção e reparos seria compensado pelas quotas decrescentes de depreciação, resultando em custos globais mais uniformes.

c) Método de unidades produzidas: esse método é baseado numa estimativa do número total de unidades que devem ser produzidas pelo bem a ser depreciado, e a quota anual de depreciação é expressa pela seguinte fórmula:

Quota de depreciação anual =

№. de unidades produzidas no ano $X$

№. de unidades estimadas a serem

produzidas durante a vida útil do bem.

O resultado da fração apresentada representará o percentual de depreciação a ser aplicada no ano $X$.

d) Método das horas de trabalho: este método baseia-se na estimativa de vida útil do bem representada em horas de trabalho, e é expresso pela seguinte fórmula:

Quota de depreciação =

no. de horas de trabalho no período $Y$

no. de horas de trabalho es.62(e)-2.70898(s)8.33699(t)-1.35585(i)9.697 
dos ativos seria representado através dos custos necessários para repor todo seu potencial de serviços ou benefícios, assumindo-se, portanto, a seguinte igualdade:

$\mathrm{CPS}=\mathrm{NRS}$

Em que:

CPS $=$ Consumo potencial de serviços e

NRS = Necessidade reposição do potencial de serviços

Para Currie (1987) e Pallot (1997 apud Carvalho, 2004) esse método demanda cálculos periódicos sobre a manutenção dos bens públicos de infra-estrutura em termos monetários. Esses cálculos seriam contabilizados não como uma provisão passiva para possíveis investimentos nesses ativos, mas como valores redutores dos ativos públicos de infraestrutura.

Quando a entidade governamental efetuar gastos com renovações, os custos dessas renovações seriam reduzidos, no período em que foram realizados, do valor da conta de manutenção diferida pois, neste instante, o potencial de serviços físicos do ativo estaria voltando aos níveis determinados pela organização que mantém seu controle. $\mathrm{Na}$ abordagem da Contabilidade por Renovação devem ser observadas distinções entre os gastos que possuem como finalidade recuperar o potencial de serviços, e os gastos que visam aumentar a capacidade esperada do potencial de geração de serviços do ativo. Os primeiros devem ser deduzidos da conta de manutenção diferida, os segundos devem ser capitalizados aos ativos.

Um pré-requisito essencial para a utilização da contabilidade de renovação para os ativos públicos de infra-estrutura é o desenvolvimento de um plano adequado de gestão desses ativos, baseado em cálculos que visem estimativas periódicas de gastos necessários de restauração do potencial de serviço. Algo que deve ser observado com relação à Contabilidade por Renovação, é o fato de que esta técnica está relacionada apenas à utilização física do ativo, ignorando desvalorizações por questões de avanços tecnológicos ou outros fatores semelhantes. 


\subsection{Limites Impostos pela Receita Federal para Fins de Contabilização da Depreciação}

Como se verificou anteriormente, a Fipecafi (2007) demonstra que a depreciação a ser contabilizada deve ser, conforme a Lei das Sociedades por Ações, a que corresponder ao desgaste efetivo pelo uso ou perda de sua utilidade, mesmo por ação da natureza ou obsolescência. Assinala, entretanto, que a tendência de um número significativo de empresas é adotar as taxas admitidas pela legislação fiscal.

Os critérios básicos de depreciação, de acordo com a legislação fiscal, estão consolidados no Regulamento do Imposto de Renda em seus arts. 305 a 323. As taxas anuais de depreciação normalmente admitidas pelo fisco para uso normal dos bens em um turno de oito horas diárias constam, todavia, de publicações à parte, da Secretaria da Receita Federal. A Instrução Normativa SRF no. 162, de 31-12-98, aprovou uma extensa relação de bens, com os respectivos prazos normais de vida útil e taxas anuais de depreciação admitidos, ampliada pela Instrução Normativa SRF №. 130, de 10-11-99.

Andrade Filho (2005) define que de acordo com o art. 305 do RIR/99, poderá ser computada como custo ou encargo, em cada período de apuração, a importância correspondente à diminuição do valor dos bens do ativo resultante do desgaste pelo uso, ação da natureza e obsolescência normal. $O$ valor da depreciação será deduzido pelo contribuinte que suportar o encargo econômico do desgaste ou obsolescência, de acordo com as condições de propriedade, posse ou uso do bem.

Isso leva ao seguinte questionamento: a depreciação é obrigatória ou facultativa?

A respeito deste assunto, em sua ementa, o Parecer Normativo CST №. 79/76 esclarece:

\footnotetext{
Respeitados os limites, mínimo de tempo e máximo de taxas, a pessoa jurídica tem a faculdade de computar ou não a depreciação dos bens do Ativo em qualquer percentual. A omissão, ou o uso de taxas normais ou inferiores, em um ou mais exercícios, não pressupõe renúncia do direito à utilização de taxas de depreciação acelerada, quando for 0 caso.
}

Se essa opinião ainda é válida, está resolvida a questão. O contribuinte contabiliza a depreciação se e quando quiser, respeitando os parâmetros de tempo e taxa. $\mathrm{O}$ art. 307 do $\mathrm{RIR} / 99$ determina as regras que estabelecem quais os bens que são passiveis, ou não, de depreciação. O RIR/99 possui diversas outras regras a respeito da dedutibilidade ou não da depreciação para empresas de diversas espécies ou atividades, mas para o objetivo de nosso estudo o que está exposto acima é o suficiente. Os arts. 309 e 310 do RIR/99 definem a quota 
e a taxa anual de depreciação dedutível, onde a quota de depreciação registrável na escrituração como custo ou despesa operacional será determinada mediante a aplicação da taxa anual de depreciação sobre o custo de aquisição dos bens depreciáveis.

\subsection{Classificação, Reconhecimento e Evidenciação dos Bens Públicos de Infra- Estrutura.}

Carvalho e Slomski (2006) mencionam que sobre os bens públicos de infra-estrutura e, sobretudo, a respeito de sua classificação, reconhecimento e evidenciação enquanto elemento contábil, estudos sugerem abordagens distintas em relação ao assunto. Embora sejam raros, pesquisadores como Mautz (1981; 1988) e Barton (2000), posicionam-se contra a classificação desses bens como ativos, apoiados na idéia de que esses bens não atendem às definições e às características de ativos, principalmente por não proporcionarem benefícios futuros em forma de entrada líquida de caixa para as entidades que os controlam.

Por outro lado, encontram-se trabalhos como os de Rowles (1992) e Pallot (1990a; 1990b; 1992; 1997) que se contrapõem às idéias de Mautz e Barton, ao defenderem que os bens públicos de infra-estrutura atendem à definição e às características de ativos. Estes autores analisam a natureza desses bens de outra perspectiva que não diretamente à sua capacidade de produzir fluxo de caixa para a entidade governamental que o controla, mas pela sua capacidade de contribuir para a entrega de bens e serviços a sociedade.

Considerando o objetivo deste estudo, concorda-se com a visão dos autores citados no parágrafo anterior, pois o Comitê do IFAC (2000) que estuda os elementos contábeis do setor Público definiu que "ativos são recursos controlados por uma entidade como resultado de um evento passado e, do qual, benefícios econômicos ou potenciais serviços são esperados".

Carvalho e Slomski (2006) explicam que esta definição pode não ser a mais abrangente entre as definições de ativos governamentais oferecidas na bibliografia contábil, mas é composta por expressões de grande riqueza para discussões e controvérsias à luz do ambiente público como: controle, recursos e benefícios econômicos e potenciais serviços. E, para o estudo em pauta, auxilia a classificar os bens de infra-estrutura como ativo depreciável, pois estes são controlados efetivamente pelo estado enquanto patrimônio público. Resultam de um evento anterior, que tem como benefício econômico o desenvolvimento da região onde é construído, e como potenciais serviços o atendimento aos cidadãos, principais acionistas do Estado, pois 
integralizam capital em forma de taxas e impostos e esperam receber os dividendos de seus investimentos (grifo nosso).

\section{Metodologia}

Para a realização deste trabalho optou-se pela aplicação da metodologia denominada estudo de caso, fundamentada na análise dos conceitos teóricos e legais de depreciação, buscando caracterizar os métodos e normas, utilizados no sistema contábil brasileiro para evidenciação da depreciação de bens imóveis. Segundo Martins (2006), é cada vez mais freqüente a condução de pesquisas científicas orientadas por avaliações qualitativas: pesquisas qualitativas, como são geralmente denominadas. A avaliação qualitativa é caracterizada pela descrição, compreensão e interpretação dos fatos e fenômenos, em contrapartida à avaliação quantitativa, denominada pesquisa quantitativa, onde predominam as mensurações.

A estratégia de pesquisa apresentada - Estudo de Caso - pede avaliação qualitativa, pois seu objetivo é o estudo de uma unidade social que se analisa profunda e intensamente. (...) Mediante um mergulho profundo e exaustivo em um objeto delimitado - problema de pesquisa - o Estudo de Caso possibilita a penetração na realidade social, não conseguida plenamente pela avaliação quantitativa.

Os dados necessários para este estudo de caso foram coletados nas demonstrações contábeis e notas explicativas disponíveis no site www.ecorodovias.com.br, de onde foram extraídos os números e informações necessárias para a montagem de tabelas e gráficos que auxiliaram a concluir este trabalho. Com base em uma pesquisa exploratória dos métodos utilizados pela empresa Ecovias dos Imigrantes S.A. que ligam a Capital ao litoral do estado de São Paulo, conseguiu-se determinar e quantificar o impacto da depreciação de bens de infra-estrutura da empresa.

Para efeito desta pesquisa abrangeu-se apenas a Rodovia Nova Imigrantes. Para isso buscou-se analisar os métodos da depreciação nos bens de infra-estrutura, mais especificamente, estradas de rodagem, bens estes que são o objeto de receita desta empresa.

\section{Análises E Discussões}

A Concessionária Ecovias dos Imigrantes S.A. iniciou suas atividades em 29 de Maio de 1998 e tem como objetivo social exclusivo a exploração, pelo regime de concessão, do sistema 
rodoviário constituído pelo Sistema Anchieta-Imigrantes-SAI, com extensão total de 177 quilômetros, de acordo com os termos da concessão outorgados pelo Governo do Estado de São Paulo.

O Sistema Anchieta-Imigrantes-SAI tem uma concessão pelo prazo de vinte anos, e mediante a cobrança de pedágios promove a manutenção e melhoria dos sistemas de operação; construção de pista descendente da Rodovia dos Imigrantes; recuperação das rodovias existentes; construção de pistas marginais; implantação de sistemas de controle de tráfego e atendimento aos usuários; conservações preventivas; implantação de sistemas eletrônicos de gestão e arrecadação de pedágios. Em 21/12/2006, por intermédio de um termo aditivo e modificativo, a companhia obteve a prorrogação do prazo de concessão por mais setenta meses, em função do reequilíbrio econômico-financeiro do contrato de concessão.

Um dos compromissos assumidos pela concessionária foi o de duplicar a Rodovia dos Imigrantes entre os quilômetros 41 e 58 (pista descendente), com término inicialmente previsto para o primeiro semestre de 2003. Este compromisso foi antecipado em 17 de dezembro de 2002 por meio da entrega da obra. (www.ecorodovias.com.br). E é nesta obra de infraestrutura, passível de depreciação que focaremos o nosso trabalho, faremos uma exposição demonstrando os métodos contábeis utilizados pela concessionária, e sugerindo sua aplicação, pelos órgãos da administração pública no que tange a depreciação de seus bens de infra-estrutura correlatos, levando-se em consideração as dificuldades de mensuração e avaliação citadas acima.

\subsection{Método de Depreciação Utilizado}

O imobilizado é registrado pelo custo de aquisição, construção ou reavaliação, deduzida da depreciação acumulada, que é computada pelo método linear. As taxas de depreciações são calculadas considerando os prazos de vida útil dos bens, prazos esses que não ultrapassam o período da concessão com o poder concedente. A depreciação desses bens é incluída na rubrica dos serviços prestados na demonstração de resultado. As principais melhorias são registradas no imobilizado e os gastos com manutenção e reparos são registrados no resultado, quando incorridos.

Os gastos com projetos de expansão, construção e melhorias, enquanto não terminados, são registrados como obras em andamento. Ao término do período da concessão, retornam ao poder concedente todos os bens reversíveis, direitos e privilégios vinculados à exploração do 
Depreciação em bens de infraestrutura: Um estudo realizado na rodovia Nova Imigrantes

Éder de Souza Diógenes, Valmor Slomski

sistema rodoviário. A Concessionária terá direito à indenização correspondente ao saldo não amortizado ou depreciado dos bens ou investimentos, cuja aquisição ou execução, devidamente autorizada pelo Poder Concedente, tenha ocorrido nos últimos 5 anos do prazo da concessão.

\subsection{Evolução do Ativo Imobilizado e da Depreciação Acumulada}

A Tabela 01 mostra a evolução do ativo imobilizado da empresa no que diz respeito às ampliações principais e a conservação da Rodovia dos Imigrantes, concernentes aos cinco últimos exercícios. Para ilustrar, colocam-se os demais itens do Ativo Imobilizado, bem como o valor total deste Ativo (Em milhares de Reais).

Os valores contabilizados nas contas de custo e conservação da rodovia referem-se apenas ao montante aplicado pela Concessionária na duplicação da rodovia "Nova Imigrantes". Além disso, cabe explicar que a Concessionária registrou em 31de maio de 2004 a reavaliação do seu ativo imobilizado (ampliação principal e sistemas de telecomunicações) em contrapartida à reserva de reavaliação no patrimônio líquido. Nas demonstrações contábeis pertinentes aos exercícios de 2001 a 2005, as taxas de depreciação aplicadas eram fixas com as seguintes alíquotas: direito de outorga da concessão, $5 \%$ (cinco por cento); equipamentos e sistemas $10 \%$ (dez por cento); veículos, $20 \%$ (vinte por cento); ampliações principais e demais ampliações de 5\% a 7\% (cinco a sete por cento) e para conservação 16,8\% (dezesseis vírgula oito por cento).

Tabela1: Custo x Depreciação (em milhares de Reais)

\begin{tabular}{|c|c|c|c|c|c|}
\hline & & $\begin{array}{c}\text { Ampliações } \\
\text { principais }\end{array}$ & $\begin{array}{l}\text { Conserv. da } \\
\text { rodovia }\end{array}$ & $\begin{array}{c}\text { Demais itens do } \\
\text { Ativo Imob. }\end{array}$ & $\begin{array}{l}\text { Total do Ativo } \\
\text { Imobilizado }\end{array}$ \\
\hline \multirow{2}{*}{2002} & Custo $^{1}$ & 800.258 & 40.891 & 244.281 & 1.085 .430 \\
\hline & Depreciação acumulada & $(64.191)$ & $(4.394)$ & $(44.343)$ & $(112.928)$ \\
\hline \multirow{2}{*}{2003} & Custo & 821.417 & 57.590 & 259.982 & 1.138 .989 \\
\hline & Depreciação acumulada & $(113.847)$ & $(8.120)$ & $(64.632)$ & (186.599) \\
\hline \multirow{2}{*}{2004} & Custo & 1.022 .344 & 66.248 & 280.768 & 1.369 .360 \\
\hline & Depreciação acumulada & $(173.344)$ & $(12.847)$ & $(87.177)$ & (273.368) \\
\hline \multirow{2}{*}{2005} & Custo & 1.022 .693 & 87.778 & 310.504 & 1.420 .975 \\
\hline & Depreciação acumulada & $(237.222)$ & $(19.954)$ & $(111.833)$ & (369.009) \\
\hline \multirow{2}{*}{2006} & Custo & 1.024 .858 & 95.900 & 386.912 & 1.507 .670 \\
\hline & Depreciação acumulada & $(300.681)$ & $(25.338)$ & $(143.211)$ & $(469.230)$ \\
\hline
\end{tabular}

\footnotetext{
${ }^{1}$ Todos os dados nomeados como custo, referem-se aos valores aplicados na construção e não estão descontados os valores referentes a depreciação acumulada.
} 
Depreciação em bens de infraestrutura: Um estudo realizado na rodovia Nova Imigrantes

Éder de Souza Diógenes, Valmor Slomski

Para 2006, foi registrada a seguinte explicação na nota explicativa numero dois, que versa sobre "Base de preparação e apresentação das demonstrações contábeis":

O processo de elaboração das demonstrações financeiras envolve a utilização de estimativas contábeis. Essas estimativas foram baseadas em fatores objetivos e subjetivos, com base no julgamento da administração para determinação do valor adequado a ser registrado nas demonstrações financeiras. Itens significativos sujeitos a essas estimativas e premissas incluem a seleção de vidas úteis do ativo imobilizado e de sua recuperabilidade nas operações, análise do risco de crédito para determinação da provisão para créditos de liquidação duvidosa, assim como a análise dos demais riscos para determinação de outras provisões, inclusive para contingência e avaliação dos instrumentos financeiros e demais ativos e passivos na data do balanço." Com isso, as taxas de depreciação aplicadas no exercício de 2006 foram: Direito de outorga da concessão, $5 \%$ (cinco por cento); equipamentos e sistemas, $17,4 \%$ (dezessete vírgula quatro por cento); veículos, 9,3\% (nove vírgula três por cento); ampliações principais e demais ampliações, 8,5\% (oito vírgula cinco por cento) (grifo nosso).

As peças contábeis da empresa demonstram claramente que os recursos financeiros captados por intermédio de operações de crédito (empréstimos) foram utilizados para honrar os compromissos firmados com a administração pública do Estado de São Paulo, no tocante a construção e manutenção da rodovia objeto deste estudo. Mas, supondo que a construção e manutenção desta rodovia não fosse concessionada, e, portanto, regulamentada pela lei 4.320/64, qual o tratamento contábil dado aos valores utilizados para a sua construção e conservação? Esta evidenciação seria de fácil entendimento para o usuário externo, e de fácil explicação por parte do gestor? Obviamente os gastos com construções e manutenção de bens de infra-estrutura são contemplados nos Planos Pluri Anuais, de Diretrizes Orçamentárias e Orçamentos Anuais, mas como a Lei não obriga a ativação e posterior depreciação destes "custos", as aplicações destes recursos não ficam bem evidenciadas nos balanços públicos.

Segundo Carvalho e Slomski (2006), no Brasil, de forma contrária ao cenário internacional, existe uma visão harmônica na prática contábil de que os bens públicos de infra-estrutura, representam, no momento de sua construção ou aquisição, uma despesa para a entidade governamental. Portanto, o que ocorre no sistema contábil das entidades da Administração Pública é que estes valores transitam pelas contas do ativo e do passivo, mas, ao serem amortizadas (pagas) não deixam qualquer evidência de utilização. Ou seja, em uma análise efetuada por um observador externo, não será detectada a necessidade desta operação de crédito, e muito menos em que este montante financeiro foi aplicado. $E$ mesmo que o financiamento das construções e/ou reformas seja feito com verba de receita própria da entidade como, por exemplo, de tributos, os valores apenas passam pelas contas, não deixando nenhuma evidência de como e para que foram utilizadas. Logo, se não fazem parte 
Depreciação em bens de infraestrutura: Um estudo realizado na rodovia Nova Imigrantes Éder de Souza Diógenes, Valmor Slomski

do ativo imobilizado, não são passíveis de depreciação, tampouco de um possível cálculo de custo de reposição, dificultando ainda mais a transparência das demonstrações contábeis.

Na Tabela 2 são apresentadas as relações entre os números que dão embasamento a esse estudo. Estes mostram a significância dos bens de infra-estrutura em relação ao ativo total, lembrando que o aumento irregular do imobilizado em 2004 se deu em virtude da reavaliação de ativos efetuada pela empresa. O aumento percentual na relação entre o valor da depreciação acumulada de bens de infra-estrutura e o ativo total é auto explicativo, pois a depreciação aumenta conforme são acumulados os valores depreciados ano a ano. Mas o mais importante nesta tabela é a verificação que, aos olhos de um observador externo, a informação contábil é clara.

Os recursos incorporados ao ativo, objetivando a construção e manutenção da rodovia, aparecem como ativo imobilizado, com origem em um evento passado, sob controle da concessionária por intermédio de contrato firmado com o governo do Estado de São Paulo e que tem o direito de cobrar pedágio pelo seu uso pelos veículos que por ela transitam (potenciais serviços), pedágio este, que representa benéficos econômicos futuros, satisfazendo assim as premissas apresentadas pelo Comitê do IFAC que estuda os elementos contábeis do setor Público.

Tabela 2: Significância dos bens de infra-estrutura em relação ao ativo (em milhares de Reais)

\begin{tabular}{lccccc} 
& 2002 & 2003 & 2004 & 2005 & 2006 \\
\hline Ativo total $^{2}$ & 1.172 .64 & 1.206 .363 & 1.318 .639 & 1.290 .349 & 1.167 .977 \\
\hline Imobilizado total $^{3}$ & 972.502 & 952.390 & 1.095 .992 & 1.051 .966 & 1.038 .440 \\
\hline Depreciação acumulada total $^{4}$ & $(112.928$ & $(186.599)$ & $(273.368)$ & $(369.009)$ & $(469.230)$ \\
\hline Bens de infra-estrutura total $^{4}$ & 772.567 & 757.040 & 902.873 & 853.881 & 795.348 \\
\hline Depreciação acumulada. BIE & $(68.585)$ & $(121.967)$ & $(186.191)$ & $(257.176)$ & $(326.019)$ \\
\hline Relação entre ativo total e BIE em \% & $65,88 \%$ & $62,75 \%$ & $68,47 \%$ & $66,17 \%$ & $68,10 \%$ \\
\hline Relação entre Imobilizado total e BIE em \% & $79,44 \%$ & $79,49 \%$ & $82,38 \%$ & $81,17 \%$ & $76,59 \%$ \\
\hline $\begin{array}{l}\text { Relação entre dep. acum. de BIE e atv tot. } \\
\text { em \% }\end{array}$ & $5,33 \%$ & $8,74 \%$ & $11,70 \%$ & $15,50 \%$ & $19,91 \%$ \\
\hline \begin{tabular}{l} 
Relação entre dep.de BIE. e dep. total em \% \\
\hline
\end{tabular} & $60,73 \%$ & $65,36 \%$ & $68,11 \%$ & $69,69 \%$ & $69,48 \%$ \\
\hline
\end{tabular}

O Gráfico 1 revela a evolução dos itens do ativo utilizados no estudo. Este exemplifica o impacto da ativação dos bens de Infra-Estrutura, bem como da depreciação destes bens.

\footnotetext{
${ }^{2}$ Valores já descontados as depreciação acumulada

${ }^{3}$ Idem nota 1

${ }^{4}$ Idem nota 1

${ }^{5}$ Para este cálculo os valores de ativo total e depreciação total foram somados.
} 
Depreciação em bens de infraestrutura: Um estudo realizado na rodovia Nova Imigrantes Éder de Souza Diógenes, Valmor Slomski

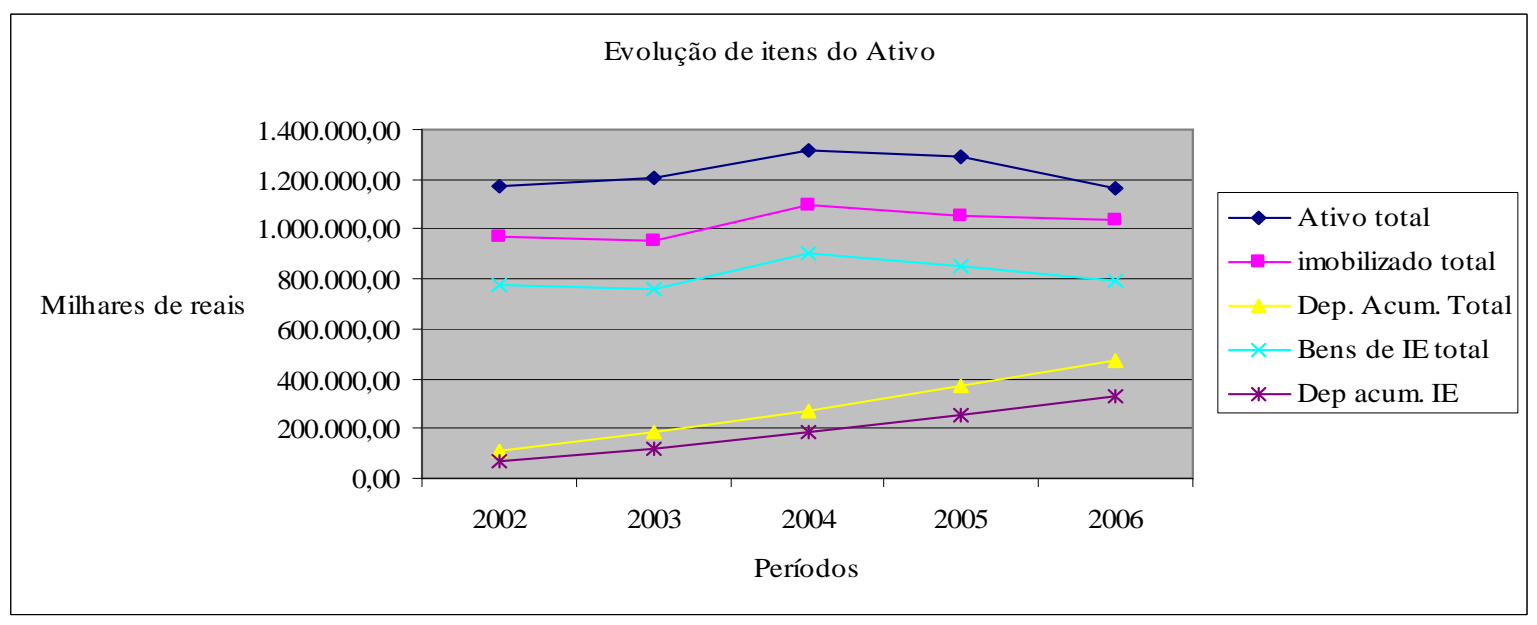

Gráfico 1: Evolução dos Itens do Ativo Imobilizado

O Gráfico 2 tem o objetivo de mostrar a representatividade, a influência e o impacto dos bens de Infra-Estrutura, bem como da depreciação destes, 
Depreciação em bens de infraestrutura: Um estudo realizado na rodovia Nova Imigrantes Éder de Souza Diógenes, Valmor Slomski

No caso estudado, a metodologia para o cálculo da depreciação acumulada foi simples, pois dividiu-se os valores aplicados na construção e conservação pelo numero de anos da concessão e as quotas são lançadas nas demonstrações sem mais problemas. Caso estas obras de infra-estrutura fossem de responsabilidade de um governo de estado como, por exemplo, a construção do Rodoanel Mario Covas, a contabilização da depreciação seria prejudicada por não haver um período de tempo limitante para o cálculo da depreciação. Mas esta opção não deve ser descartada, pois a legislação define em anos os valores a serem depreciados para outros bens do ativo imobilizado.

Também se poderiam fazer estudos para definir os limites para a depreciação dos bens de infra-estrutura, já que a Instrução Normativa da Secretaria da Receita Federal №.162 de 31 de Dezembro de 1998 define em 4\% (quatro por cento) ao ano a depreciação para pontes e elementos de pontes, torres, pórticos e edificações, os bens de infra-estrutura poderiam sem anexados a esta classificação. A metodologia denominada como Contabilidade por Renovação poderia ser uma opção válida, na medida em que a economia do país alcançou uma estabilidade que torna possível efetuar cálculos abrangendo a necessidade de manutenção dos bens de infra-estrutura, objeto deste estudo, com acurácia satisfatória, utilizando-se como base os gastos efetuados nos anos anteriores, tanto pelos governos, quanto pelas concessionárias de estradas de rodagem.

Carvalho (2004) explica que o Gasb (1999) oferece duas perspectivas aos seus jurisdicionados. A primeira é que seja feita a depreciação dos ativos de infra-estrutura como se fossem ativos fixos normais, considerando a seguinte recomendação: "a despesa de depreciação deve ser mensurada pela alocação do custo líquido do ativo depreciado (custo histórico menos o valor residual estimado) sobre sua vida útil estimada, em uma base sistemática e racional" (Gasb, 1999). A segunda opção oferecida, que o Gasb (1999) chama de modified approach, recomenda que os ativos de infra-estrutura não sejam depreciados, conquanto que se cumpram duas exigências:

Primeiro o governo gerenciará os ativos de infra-estrutura selecionados, utilizando um sistema de gestão de ativos que tenha as seguintes características:

a) Manter um inventário atualizado dos ativos de infra-estrutura selecionados;

b) Desenvolver condições de avaliar os ativos de infra-estrutura selecionados e sumarizar os resultados, utilizando escalas de mensuração;

c) Estimar, a cada ano, o valor anual de manutenção e conservação dos bens de infra-estrutura selecionados, nas circunstâncias do nível estabelecido e evidenciado pelo governo

Segundo, o governo declarará, por escrito, que os ativos de infra-estrutura selecionados estão sendo preservados próximo dos níveis de condições estabelecidos e evidenciado por ele (GASB, 1999, p. 12). 
$\mathrm{Na}$ ocasião da escolha de não se depreciarem os ativos, o governo que o fizer deverá considerar como despesa do período todos os gastos que visem preservar a vida útil dos ativos, capitalizando apenas os gastos que proporcionem o aumento ou melhoria na capacidade ou eficiência do ativo de infra-estrutura (Gasb, 1999). Isso, segundo Rowles (1992) e Pallot (1997), é uma espécie de contabilidade por regime de caixa, portanto, incoerente com o regime de competência adotado pelo Gasb.

O Ifac (2003), mesmo cônscio das dificuldades de se determinar a vida útil dos ativos de infraestrutura, considerando-os como equivalentes à propriedades, instalações e equipamentos, faz a seguinte recomendação:

O valor depreciável dos itens de propriedade, instalações e equipamentos devem ser alocados em bases sistêmicas sobre sua vida útil. O método de depreciação usado deve refletir a base em que os benefícios econômicos ou os potenciais serviços sejam consumidos pela entidade (IFAC, 2003, p. 536).

Carvalho (2004) assinala que é interessante notar que as abordagens dadas para a depreciação pelas duas organizações são distintas. O Gasb (1999) enfatiza a alocação de custos, ou seja, a distribuição do custo ou outro valor do ativo ao longo do tempo. O Ifac (2003), por sua vez, dá ênfase na abordagem da diminuição da capacidade de geração dos serviços do ativo. Nesse caso a depreciação é interpretada como o declínio do potencial de geração dos serviços de ativos de longa duração.

\section{Conclusão}

Este trabalho teve como objetivo principal estudar a metodologia de depreciação de bens de infra-estrutura, mais especificamente de estradas de rodagem, utilizada pela empresa Ecovias dos Imigrantes S.A., que é administradora do Sistema Anchieta-Imigrantes, concessionado à empresa pelo Governo do Estado de São Paulo. Verificar a sua possível aderência às demonstrações financeiras dos entes públicos da administração direta. Partiu-se de uma descrição objetiva, embasada na teoria existente, das definições de depreciação, suas aplicações e os limites impostos pelo fisco, e apresentou-se também as doutrinas de dois órgãos internacionais, Gasb e Ifac a respeito do tema, além de uma metodologia alternativa que é o Método de Contabilidade por Renovação.

Foram analisadas as demonstrações financeiras da Ecovias dos Imigrantes S.A. e, com base nos resultados obtidos, acredita-se que é possível aplicar a metodologia utilizada pela 
concessionária supracitada, desde que se tenham métodos suficientemente substanciais para avaliar os bens de infra-estrutura, e sejam definidas, utilizando estes mesmos métodos, quotas de depreciação para estes bens que reflitam consistentemente o seu desgaste.

Registre-se que foi utilizado apenas o método de uma empresa, que é relativamente novo, em comparação à doutrina aceita pelos profissionais contabilistas. Torna-se necessário aprofundar o assunto, abrangendo outras empresas que têm o mesmo objetivo econômico, e analisar também outras metodologias aplicadas por governos de outros países, para verificar se, entre estas, não existe uma que seja mais adequada às nuances existentes nos bens de infra-estrutura das entidades da administração pública do Brasil. Tudo em prol da redução da assimetria de informações entre o governo e o usuário/acionista do Estado.

Com base no estudo foi possível entender melhor a metodologia e a teoria existente a respeito de depreciação, e estudar como a administradora do Sistema Anchieta-Imigrantes trata a depreciação de seus ativos de infra-estrutura. Conclui-se que, embora a metodologia seja aplicável à contabilidade pública, ainda persiste a necessidade de estudos mais aprofundados a respeito da ativação destes bens, bem como de metodologias aderentes para a contabilização da depreciação destes referidos bens.

Este estudo limitou-se a apresentar a teoria contábil referente a depreciação e estudar o método de depreciação para bens de infra-estrutura, mais especificamente de estradas de rodagem, utilizado por uma concessionária. Analisaram-se as demonstrações financeiras de cinco anos, mas não foi possível, como era o intuito inicial, fazer uma entrevista com o profissional contábil responsável por esta contabilização.

O resultado do trabalho suscitou interesse por estudar metodologias aplicadas em outros países, e mesmo por outras empresas que detenham concessão de exploração de bens de infra-estrutura que sejam de propriedade do estado. Isso para que os resultados apontados neste estudo sejam corroborados ou descartados, ou mesmo para recomendar uma abordagem diferenciada a respeito do assunto. 


\section{Bibliografia}

ANDRADE FILHO, E. 2005 O. Imposto de Renda das Empresas. 2o ed. São Paulo: Atlas, 163 p.

CARVALHO, E.M. 2004. Bens Públicos de Infra-Estrutura: Um Estudo Qualitativo das Práticas relacionadas ao Reconhecimento e Evidenciação Contábil. São Paulo, SP. Dissertação de Mestrado. Universidade de São Paulo - USP, p. 55-67-69.

CARVALHO, E.M. e SLOMSKI, V. 2006. Bens Públicos de Infra-estrutura: Um Estudo Crítico-Dialético das Práticas Relacionadas a Reconhecimento e Evidenciação Contábil. In: 30ํ Encontro da ANPAD, Salvador, CD-ROM.

Ecovias dos Imigrantes. Disponível em http://www. ecorodovias.com.br, acesso em 14/10/2007.

Governmental Accounting Standard Board - GASB. 1999. Statement N ‥34; basic financial statements - and management's discussion and analysis - for state and local governments. Connecticut, $11 \mathrm{p}$.

IBRACON. Normas Internacionais de Contabilidade. São Paulo: IBRACON, 1997, p. 202-203.

International Federation of Accountants - Ifac, Public Sector Committee. Ipsas 17: Property, plant and equipment. New York, 2003. , 536 p.

IUDíCIBUS, S., MARION, J.C., PEREIRA, E. e SLOMSKI, V. 2001. Dicionário de Termos de Contabilidade. São Paulo, Atlas, 69 p.

LOPES de SÁ. 1992. Obsolescência e Depreciação. Boletim IOB no. 51, 433 a 435 p.

FIPECAFI. 2007. Manual de Contabilidade das Sociedades por Ações: Aplicável ás Demais Sociedades. Diretor responsável Sérgio de Iudícibus; coordenador técnico Eliseu Martins; supervisor de equipe de trabalho; Ernesto R. Gelbcke. - 7o ed. São Paulo, Atlas, 194 a 197 p.

MARION, J.C. 1998. Contabilidade Básica 6ạ ed. São Paulo. Atlas, 174-175 p.

MARTI NS, E. 1992. Depreciação, Afinal o que é? Boletim IOB no . 30, 256 p.

MARTINS, G.A. 2006. Estudo de Caso: Uma Estratégia de Pesquisa. São Paulo, Atlas, 11 p.

SLOMSKI, V. 2003. Manual de Contabilidade Pública: Um Enfoque na Contabilidade Municipal, de Acordo Com a Lei de Responsabilidade Fiscal. 2o ed. São Paulo, Atlas, 101 p.

Submissão: $20 / 11 / 2008$ Aceite: $16 / 12 / 2008$ 